\title{
Linguistic intelligence enhancement at basic level learners in Nepal
}

\section{Sakun Kumar Joshi}

\begin{abstract}
This paper explores English language teachers' strategies to enhance linguistic intelligence of students studying at basic level in community schools in Nepal employing a qualitative research design.It aims to describe different techniques employed by English language teachers to develop students'linguistic intelligence. The research participants were English language teachers teaching in community schools in Kathmandu and interviewed by using a semi-structured questionnaire to gather data to fulfil its purpose. The findings reveal that awakening students is an essential tool for enhancing linguistic intelligence along with meaningful exposure and atomistic learning provide opportunities for enhancement of linguistic intelligence at basic level.
\end{abstract}

Keywords: Atomization, cognitive diversity, focused teaching, linguistic intelligence

\section{Introduction}

Numbers of academic studies recognized that knowledge and technology transfer among the spheres of industry, academia and state (D'Este, Llopis \&Yegros, 2013). The knowledge and technology transfer builds up cognitive diversity. The cognitive diversity has a direct "impact on performance" (Younis, 2018, p. 160) of the learners. It makes differences between the perception and cognition. Perception is related to how an individual captures the information needed for processing (Bromiley \& Rau, 2016) and, cognition refers to how an individual uses the information (Anderson, 1990). Cognitive diversity results from a group that includes intelligences existing in each learner. It implies that the learners think differently and have different problemsolving methodologies. Cognitive diversity reflects diversity in terms of expertise, experiences, and perspectives (Miller, Burke \& Glick, 1998).

Cognitive diversity adopts creativity, and "creativity is the production of novel and useful ideas regarding products, services, processes, and procedures by an individual" (Younis, 2018, p. 160).Cognitive diversity is the ability of the group to differently process, perceive and interpret information and varying stimuli (Milliken \& Martins, 1996). Cognitive diversity ultimately reflect the multiple intelligences existing in a learner.

The theory of multiple intelligences views each learner through the lens of creativity. It remains always a matter of interest -for teachers, teacher trainers and ELT practitioners -that how a learner is equipped with Multiple Intelligences (MIs), introduced by Howard Gardner in 1983, in English Language Teaching (ELT). The MI theory, specially, addresses the ranges of intelligencesexisting in a learner. According to this theory, no learner is useless and helps in learning possible polishing the intelligence/s of each individual(Armstrong, 2009). 
Gardner's theory of multiple intelligences brought revolution in the field of teaching. This theory states that each person is unique and has a blend of intelligences like linguistic, logical, spatial, musical, kinesthetic, interpersonal, intrapersonal, naturalistic and so on. Moreover, human beings possess moral and spiritual intelligences as well. Thus, the MI theory gives teachers a complex model of designing curriculum and accessing teaching techniques. As Lie (2012, p. 3) states, "... the theory is an account of human cognition in its fullness. Instead of seeing people as rational or irrational, Gardner describes human beings as organisms possessing a set of intelligences. Second, we each have a unique blend of intelligences". Gardner (1983) argues that each learner is equipped with these intelligences. Only the teachers need to guide and motive learners to trigger their capacity.

The MI theory highly supports that each learners is intelligent either linguistically, logically, musically, spatially, interpersonally, intrapersonally, bodily-kinesthetic or naturally. These are different kinds of intelligences as identified by Gardner. Heming (2008) states, "Gardner's theory maintains that each person possessed several intelligences which are used to carry out specific tasks" (p.1). Moreover, Lunenburg and Lunenburg (2014) state, "The theory of multiple intelligences is a theory of intelligence that differentiates it into specific modalities, rather than seeing intelligence as dominated by a single general ability" (p.1).

The MI theory suggests that teaching methodologies and techniques adopted by teachers with innate capacity of the learners determine the success in learning. Each learner is special and capable to perform better in his/her area of interest. Only focused teaching is essential for identifying the learners' intelligence. Therefore, linguistically excellent learners are not necessarily intelligent logically or musically or so on. Thus, intelligence is determined by the learning rate and the nature of learner (Armstrong, 2009).

The MI theory is a pluralized way of understanding the intellect. Recent developments in cognitive science, developmental psychology and neuroscience suggest that each person's intelligence is actually made up of autonomous facilities. That's why, this theory has a great implication in education. In academic practices, the MI theory "allows a wider scope for measuring various kinds of intelligence which can be employed in teaching and learning and in helping students in developing their cognitive skills and their personal motives" (Sulim, 2012, p.268).

The MI theory advocates for learner-differences. With the help of the theory of multiple intelligences (MI) in teaching, teachers are able to change their teaching strategies and cater for the individual differences of learners. The MI theory has "generated much excitement in the educational community, since it formed a marked contrast to the traditional view that individuals possess only one general intelligence" (Baum, Viens\& Slatin 2005, as cited in Gouws, 2007, p. 61). So, no learner lacks intelligence though the degree of intelligence may vary. That is, highly linguistically intelligent learner may not be equally intelligent in logical intelligence or spatial intelligence. However, one sort of intelligence automatically helps building next intelligence. 
The MI theory is taken as a framework for thinking and rethinking, and playing with the ideas in relation to the intelligence. Richards and Rodgers (2010) state, "Applications of MI in language teaching have been recent (p.118)" and it has brought newness in teaching and learning methods. So, MI theory is the theory of learning new models of intelligences which are really applicable in teaching and learning. The learners with multiple intelligences can easily learn two or more languages very fast. The processing takes place as central to the whole life of the language learner and user. Therefore, language learning process takes place through integrative approach in a better way. Language learning is not only limited to use and adopt linguistic activities but it encompasses other aspects like music, interpersonal skill, logical reasoning and kinesthetic activities.

MI theory claims that the learners learn best when they work information which is presented and thatsuits their intelligence. The ability of learning depends upon the intelligence possessed by the learners. Therefore, the MI theory has a wide application in education (Gouws, 2007). In this regards, this paper aims to explore English language teachers' strategies to enhance linguistic intelligence of the students studying at basic level in community schools in Nepal by focusing on "How do English language teachers perceive ELT strategies for building linguistic intelligence?"

\section{Literature Review}

Intelligence is considered to be mental activity which is directed toward purposive adaptation to, selection, and shaping ofreal-world environment relevant to one's life. According to Shakouri, Sheikhy and Teimourtash (2017) intelligence is composed ofthree factors: analytical intelligence (i.e., the ability to solve problems), creative intelligence (i.e., theability to deal with the new situation using past experiences and current skills), and practical intelligence (i.e.,the ability to adapt to a changing environment). Hence, intelligence is such an ability that leads towards problem solving, situational analysis and environmental adaption. In this regard, Lohman (1989) takes intelligence as information processing ability. For Gardener (2011) intelligence is "a property of all human beings" (p. xv). Each person is intelligent, therefore.

The theory of Multiple Intelligences (MIs) supports that each learner is special and has special capacities. Lunenburg and Lunenburg (2014) assert that the MI theory "... has emerged from cognitive research and documents the extent to which students possess different kinds of intelligence and therefore learn in different ways" (p.13). The learner needs to be encouraged towards innovative and sensitive learning. Multiple activities should be applied in the classroom for developing real intelligences of the learner.

The MI theory asserts that each learner is equipped with different intelligences (viz. linguistic intelligence, logical-mathematical intelligence, bodily-kinesthetic intelligence, musical intelligence, visual-spatial intelligence, interpersonal intelligence, intrapersonal intelligence, musical intelligence, existential intelligence and naturalistic intelligence) that manifest varied 
abilities of the learner (Gardner, 2006). Gardner (ibid) further exposes three intelligences that may exist in learners are "humor intelligence, cooking intelligence and sexual intelligence" (p.18).

Linguistic intelligence, concerned with linguistic capacity of a learner, entails with the word power of the learners. According to Malonee (1997), linguistic intelligence is "the ability to use words effectively" (p. 3). This intelligence involves the knowing which comes through language; through reading, writing, and speaking. It, in the words of Heming (2008), addresses "everything having to do with language, speech, reading, and writing" (p.6). Thus, linguistic intelligence involves understanding the order and meaning of words in both speech and writing and proper use of language. It involves understanding the sociocultural nuances of a language, including idioms, plays on words, and linguistically-based humor. Linguistically intelligent learners have highly developed skills for reading, speaking, and writing and you tend to think in words. They probably like various kinds of literature, playing word games, making up poetry and stories, engaging in involved discussions with other people, debating, formal speaking, creative writing, and telling jokes.(Gardner, 1983)

According to Lunenburg and Lunenburg (2014), "Linguistic intelligence refers to an individual's sensitivity to the sounds, rhythms, and meanings of words; and sensitivity to different functions of language" (p. 2). Linguistically intelligent learner is able to use words in ways that are more skillful, useful, and creative than the average person. Such kind of learner is able to use language to convince others of his/her own position.

According to Gardner (2009) "Linguistic intelligence is also passes our empirical tests" (p. 13). Linguistically intelligent learner can memorize and recall detailed or complex information, is better at explaining and teaching concepts and ideas to others and can enjoy using language to talk about language itself. Gardner compares linguistically intelligent people with a good poet. He argues, "The poet must be superlatively sensitive to the shades of meanings of words and must try to preserve as many of the sought-after meanings as possible" (p. 77). It is also concerned with language skill and its use. (Hali, 2017)

Linguistic intelligence is defined as everything having to do with language, speech, reading, and writing. It is said to be the most widely shared human competence. Poets, journalists, and novelists tend to have the highest level of understanding to this intelligence (Heming, 2008). Linguistically intelligent students are good at cracking jokes, telling stories, writing poems, essays and doing crossword puzzles. (Gardner, 2006)

Poets, authors, orators, speakers, and attorneys exhibit strong linguistic intelligence (Lunenburg \& Lunenburg, 2014). So, linguistically intelligent people play with words. They are word smart. According to Gardner (2004, as cited in Shahrokhi1, Ketabi \& Dehnoo, 20103, p. 190), linguistic intelligence is "sensitivity to the meaning and order of words". Linguistic intelligence, therefore, is concerned with high sounding of word power. Linguistic intelligence is an ability tothink in words and use the words to communicate one's thought. This is the capacity 
to use words tocommunicate is a skill that comes from the temporal cortex on the left side of the brain (Shakouri, Sheikhy\&Teimourtash, 2017).

\section{Methodology}

This study employs a phenomenological research design that "describes the meaning of several individuals of their lived experiences" (Cresswell, 2007, p. 57) and interview "the elicitation of data by one person from another through person-to-person encounters" (Nunan, 2010, p. 231) as a technique for data collection. I collected qualitative data -which are recorded in nonnumerical form, such as transcripts ... (Nunan, 2010, p.231) and employed qualitative analysis. I interviewed my participants and transcribed the record. Each participant was interviewed for almost an hour.There lived experiences and practices for enhancing linguistic intelligence were sought while interviewing.

The participants of the study consisted of three English language teachers teaching at basic levelin community schools in Kathmandu. Among them, one was male and two were female ranging the age of 30 to 35 years and having an experience of teaching for more than 5 years. Academically all of them had completed Maters' Degree in Education specializing English language, and they were fully trained on English language teaching as well. One female English teacher was trained on Montessori teacher-training as well. The participants were termed as T1, $\mathrm{T} 2$ and $\mathrm{T} 3$ in order to maintain confidentiality and considering the ethical perspective of research.

I analyzed the data deriving three global themes from the interview based on qualitative approach. According to Nunan(2010, p. 231) qualitative data refers to the "data recorded in nonnumerical form", whereas Best and Kahn (2006)assert that qualitative data "yield detailed, thick description"(p. 250). The data gathered based on the experiences and practices of the participants. The information obtained from the participants was coded, interpreted and analyzed. The irrelevant information were excluded in the limits of research question. Finally, information was discussed and conclusion was drawn.

\section{Results and Discussion}

\section{Linguistic Intelligence Enhancement at Basic Level Learners in Nepal}

The study on linguistic intelligence enhancement at basic level learners in Nepal is based on the theory of multiple intelligences (Gardner, 1983). To conceptualize the cognitive diversity of the learners in association of linguistic intelligence, I have drawn theoretical assumptions from the multiple intelligences (MI) theory. According to Gardner (2006, p. 3) "intelligence has proceeded apace." Every learner is able to learn in his/her pace, which is determined by the rate and route of learning (Ellis, 1985).

Linguistic development -along with other development - equally be possibly developed due to a common development route. Different outcomes in language can be seen due to the individual differences among learners. There are multiple cognitive factors which help learning(Mitchell \& Myles, 2004). Interviewing the English teachers, I have developed three global 
themes for building linguistic intelligence of the learners. Basically, teachers have suggested three strategies viz. awakening awareness, exposure and atomization for building linguistic intelligence of English language learners. The study, in this regard, contributes to excel knowledge of English language teachers. It guides teachers teaching English as second or foreign language.

\section{Awakening}

On building linguistic intelligence, awareness awakening is crucial. It is concerned with the conscious raising in learning. It is also called awareness raising for learning. My participants focused on various techniques of raising students towards learning. Teachers focus on making students aware of learning which helps teachers to make meaningful teaching. While interviewing, T2 opines "... if students are not aware of their learning, teachers cannot teach". So, awakening is highly associated with consciousness raising and motivating learners. In this regard T1 states:

First of all a teacher must awaken his learners.... Teachers are awakener in fact. Teachers have to think whether their learners are sleeping... if students are sleeping, they not aware of importance of learning. ...teachers need to make some efforts at any cost.

Hence, awakening learners is activation their intelligence.

This short of effort should be handled by the teachers. As an awakener, teachers should employ some specific techniques in his or her teaching; and attract learners to their study. In this regard, T1 further says, "If the students are iron, teachers should act as a magnet". This states that student-teacher relation is intermingle. Teacher's behaviours and activities play a crucial role to make students learn and get success.

Learning becomes meaningful when teachers motivate learners with its importance. According to Mallonee (1997), "effective learning takes place when teachers instruct ina variety of ways, providing opportunities for instruction and concept development" (p. 3). Supporting this view, T2 argues that "teacher should be instructor ... tactful teachers guide students with many ways". That is, straight forward instruction is needed to make students aware of learning.

\section{Exposure}

Exposure refers to the contact that the learner has with the language that they are trying to learn. It is concerned with either general or specific language. Furthermore, it also refers to contact outside the classroom (British Council, 2018). Referring to build linguistic intelligence, it is very crucial to expose the learners towards learning. Miller (n. d. p. 2) opines as, "When a child understands the importance of understanding a language and can see how it directly applies to their life, they learn faster". She further asserts that, "When they are interested in learning a language and they see meaningful connections to their lives, they begin to take risks to produce language, which helps them to acquire it faster".

All English teachersneed to stress on "meaningful exposure".Such exposure motivates learners; and such a kind of learning leads better performance. Focusing on the importance of 
exposure, T1 says, "Exposure builds up learners' general linguistic intelligence". He further argues:

exposure is important. .... It helps for language acquisition. If parents are multilingual, children also acquire multiple languages easily. . . homely environment and school environment must create learning environment.

Homely environment is essential for better learning. Miller (n. d. p. 1) stresses that the home language of a child has direct impact on linguistic development. She goes on saying, "Parents who prioritize language learning are more likely to push their child to keep trying even when it feels difficult". Therefore language development is confined with homely linguistic environment and exposure gained at school. My participant (T2) stresses on oral and written practices as exposure. She says:

... for better learning, oral and written practices are very important tools. Parents should make their children read and write at home. ...teachers need to focus on the four skills. . . reading through meaningful recitation helps for language development.

Undoubtedly speaking, besides biological factors, exposure is one of the key factors for enhancing first language acquisition. According to Kennedy (1973), a child who begins to acquire his L1 is normally exposed to a rich linguistic environment, consisting of a range of simplified grammatical and lexical items. In T3's views, "no listening-speaking, no learning; no readingwriting, no learning". Basically she focuses on language skills as learning exposure. Learning is all about development oflanguage skills.

\section{Atomization}

Learning is typically characterized as acquisition of new beliefs. To the extent that learning should be guided by the atomistic fashion. This sort of learning helps to make learning as distributed neural nets. However, fully distributed neural nets are effective at learning to perform certain tasks in language learning. Moreover, teaching should be based on the tasks relating to perception and motor control. (Robert, n. d. p. 3)

According to $\mathrm{T} 1$ atomistic reading is essential for building linguistic intelligence. He argues that teachers should be developing "sensitivity to words, grammar and their context". He further goes on saying as:

... teachers can teach by developing analytic skill. There is a need of a focused practice for developing linguistic knowledge. ...language should be simplified and broken down into the short and simple manner.

In order to build linguistic intelligence of the learners, language teaching goes in a simplified manner. Teachers need to able to address from various points of views. Regarding the controversy in grammar teaching Thornbury (1999, p. ix) states, "Grammar teaching has always been one of the most controversial and least understood aspects of language teaching". However, 
my research participants stress on the importance of grammar teaching. According to them grammar teaching is crucial for linguistic development. A participant (T1) says, " . . teaching should be focused in word grammar." He further utters" . . grammatical categories of the words should be taught. Any vocabulary we are going to teach should be made familiar either the word falls under noun or adjective or verb and anything else."

Henceforth, acquisition of L1 takes place within the context of a long period of physical and cognitive development and of socialization. The language is acquired in the context of a community of speakers. In emphasizing the importance of exposure in L1 acquisition Steinberg (1982, as cited in Ismail, 2018) says, " ...the nature of the speech and environment input which children receive is especially contrived to assist language learning and that unfortunate children who have been exposed to language mainly through television or by overhearing adults' conversation do not acquire significant language knowledge".

\section{Conclusion}

This study concludes that learning cannot be drastically changed in a fortnight. It needs regular practice. Appropriate teaching methods and proper learning procedures help in knowledge construction in a great deal. The MI theory pluralizes the traditional concept of intelligence. Intelligence is not only questioning and answering skill of a learner but it is a computational capacity - a capacity to process a certain kind of information - that originates in human biology and human psychology.Therefore individual differences occur in learning; and learning is fostered by awakening, exposure and atomization. The teachers need to expand their repertoire of techniques, tools and strategies in order to make teaching more effective; and should adopt such ways of teaching that each learner has different ways to learn, remember, perform and understand.

The participants reported that learners' intelligence entails the ability to solve problems. Thus, building linguistic intelligence is to make students able to solve their word problems. In fact, linguistically intelligent learners are word smart. Therefore teachers need to adopt problem solving approaches to obtain the goal by locating the appropriate route of learning. Regarding strategic instruction Gardner's theory of multiple intelligences requires teachers to adjust their instructional strategies in order to meet student's individual needs. The participants of the study suggested that awakening visualizes the importance, exposure maximizes the motivation and atomization triggers to problem solving.

\section{References}

Anderson, J. R. (1990). Cognitive psychology and its implications: A series of books in psychology. New York: Freeman/Times Books/Henry Holt \& Co.

Armstrong, T. (2009). Multiple intelligences in the classroom. Alexandria: ASCD Books.

British Council (2018). Retrieved on 5 July, 2018from:https://www.teachingenglish.org.uk/ article/exposure 
Bromiley, P.\& Rau, D. (2016). Social, behavioral, and cognitive influences on upper echelons during strategy process: A literature review. Journal of Management, 42(1), 174-202. Retrieved from:https://doi.org/10.1177/0149206315617240

D’Este, P., Llopis, O. \&Yegros, A. (2013). Conducting pro-social research: Cognitive diversity, research excellence and awareness about the social impact of research. Centre for Science and Technology Studies (CWTS), Leiden University: The Netherlands. Retrieved from:https://bit.ly/2mYaqoY

Gardner, H. (1983). Frames of mind: The theory of multiple intelligences. New York: Basic Books. Retrieved from:https://epdf.pub/frames-of-mind-the-theory-of-multiple-intelligences. html

Gardner, H. (2009). Multiple intelligences. New Horizons: Basic Books.

Gardner, H. (2011). Frames of mind: The theory of multiple intelligences. Basic Books: New York Gouws, F. E. (2007) Teaching and learning through multiple intelligences in the outcomes-based education classroom, Africa Education Review, 4:2, 60-74, DOI: 10.1080/18146620701652705. doi.org/10.1080/18146620701652705

Hali, N. I. (2017). The actualization of literary learning model based on verbal-linguistic intelligence. Internal Journal of Education and Literary Studies. 5:4, 42-48. Retrieved from: http://dx.doi.org/10.7575/aiac.ijels.v.5n.4p.42

Heming, A. L. (2008). Multiple intelligences in the classroom. Honors College Capstone Experience/Thesis Projects. Paper 138. Retrieved from: http://digitalcommons.wku.edu/ stu_hon_theses/138

Kennedy, G. (1973). Conditions for language learning.' In Oiler, J. W. and Richards, J. C. (Eds.). Focus on the learner: pragmatic perspectives for the language teacher. Rowley, Mass.: Newbury House Publishers.

Lie, S. (2012). Applying multiple intelligences theory in undergraduate EFL classes.Qingdao University.

Lohman, D. F. (1989). Human intelligence: An introduction to advances in theory and research. Review of Educational Research, 59(4), 333-373.

Lunenburg, F. C.\&Lunenburg, M. R. (2014). Applying Multiple Intelligences in the Classroom: A Fresh Look at Teaching Writing. International Journal of Scholarly Academic Intellectual Diversity, 16(1), pp. 1-14.

Mallonee, R. L. (1997). Applying multiple intelligence theory in the music classroom. ERIC: UD Department of Education.

Miller, C., Burke, L., \& Glick, W. (1998). Cognitive diversity among upper-echelon executives: implications for strategic decision processes. Strategic Management Journal, 19, 39-58.

Miller, A. (n. d., July 6). 9 factors that influence language learning [Blog Post]. Retrieved from: 
https://www.whitbyschool.org/passionforlearning/9-factors-that-influence-languagelearning

Milliken, F. J., \& Martins, L. L. (1996). Searching for Common threads: Understanding the multiple effects of diversity in organizational groups. Academy of Management review, 21, 402-433.

Curriculum Development Centre (2007). National Curriculum Framework for School Education in Nepal, 2007. Retrieved from: https://www.moe.gov.np/assets/uploads/files/NationalCurriculum-Framework-2007-English.pdf

Nunan, D. (2010). Research methods in language learning. Cambridge: Cambridge University Press.

Richards, J. C.\& Rodgers, (2010). Approaches and methods in language teaching. Cambridge: Cambridge University Press.

Robert, C. (nd). Atomistic and holistic learning. Retrieved from: http://grantome.com/grant/NSF/ SES-9976739

Shahrokhi, M. Ketabi, S.\& Dehnoo, M. A. (2013). The relationship between multiple intelligences and performance on grammar tests: Focusing on linguistic intelligence. Journal of basic and applied scientific research, 3(9), 189-194

Shakouri, N.,Sheikhy, B. R. \&Teimourtash, M.(2017). On the relationship between linguistic intelligence andrecalling lexical items in SLA. International Journal of Research Studies in Education, 6(4), 29-36.

Smeil, J. (2018). Language learning and second language learning. Retrieved from http:// www.melta.org.my/index.php/11-melta-articles/160-language-exposure-and-secondlanguage-learning

Sulim, G. H. S.(2012). Prediction of the correlation between the strategies of the teaching methods and the multiple intelligence of some graduate female students at Imam Mohammad Ibn Saud Islamic University. Procedia - Social and Behavioral Sciences 47, 1268 - 1275. doi: 10.1016/j.sbspro.2012.06.810

Thornbury, S. (1999). How to teach grammar. England: Pearson Education Limited.

Younis, R.A.A. (2018). Cognitive Diversity and Creativity: The Moderating Effect of Collaborative Climate. International Journal of Business and Management, 14 (1), 2019, 159-168.

\section{The Author}

Sakun Kumar Joshi teaches English at Tribhuvan University in Mahendra Ratna Campus. He is perusing M. Phil. in English Education from TU. His areas of specialization incorporate technical translation, professional development and teacher training. He has presented papers in national and international ELT forums. 